\title{
Experiências da prática associativa no Brasil (1860-1880)
}

\section{Cláudia Maria Ribeiro Viscardi}

O estudo dos setores excluídos tem sido composto predominantemente de reflexões acerca dos mecanismos de repressão e exclusão sociais por parte do Estado e do mercado, bem como das alternativas de resistência a tais mecanismos. Para tal, as contribuições da Historiografia Social Inglesa foram vastas, sobretudo quando, após a década de 1960, seu encontro com a Antropologia permitiu o nascimento da História Social da Cultura na qual destacaram-se as clássicas contribuições de E.P. Thompson em suas pesquisas sobre o processo de formação da classe trabalhadora inglesa. Tendo tal classe sido formada após 1830, conforme assevera Thompson, ${ }^{1}$ ou entre as décadas de 1880 e 1890, como expressou a contraposição de Hobsbawm a ele, ${ }^{2}$ o que se destaca nas análises produzidas foi a preocupação com a interferência de fatores extra-econômicos no processo de formação de uma consciência de classe, para a qual foram fundamentais as dissidências religiosas, as festividades populares, os rituais e símbolos compartilhados pelos trabalhadores, as experiências prévias de associativismo, entre outros.

A partir deste novo paradigma, as pesquisas foram estendidas aos trabalhadores que não se inseriam no movimento operário, ou seja, sobre aqueles que não compunham a minoria organizada e militante. Nascia assim o estudo dos trabalhadores que se encontravam fora do mercado formal de trabalho. Esta condição impedia a sua participação nos mecanismos institucionais de luta operária, tais como os sindicatos em suas diferentes formas de luta como as greves, a imprensa operária ou a militância política. Daí se explica a mudança de foco refletida na valorização de formas alternativas de resistência dos trabalhadores contra os abusos do capital.

Inserido neste novo paradigma, o presente trabalho se propóe a estudar os trabalhadores que se encontravam alheios às intensas lutas operárias que se travavam no Brasil a partir do final do século XIX. Mas, ao 
mesmo tempo, diferencia-se das abordagens predominantes que priorizaram a análise do processo de exclusão e de resistência. Resistindo ao conceito de resistência ${ }^{3}$ - tão largamente utilizado no Brasil - pretende-se estudar as estratégias construídas no seio da própria sociedade civil com vistas à sua sobrevivência, através de iniciativas que revelavam a busca por amparo e proteção social através da ajuda mútua. Tal busca, porém, não se dava pela reivindicação de um Estado previdenciário. No contexto de afirmação de uma ideologia liberal, que convivia com uma sociedade civil ainda muito fragmentada, predominou a opção pela auto-organização, através do fortalecimento de associaçōes de ajuda mútua, sem a interveniência do Estado, embora isto, como será visto, nem sempre foi possível.

Em síntese, a pesquisa que desenvolvemos há alguns anos, propõe uma reflexão acerca das experiências conhecidas como mutualistas e filantrópicas, de caráter leigo, nascidas na sociedade brasileira a partir da primeira metade do século XIX e que tomaram corpo nas primeiras décadas do século XX, proliferando-se em várias regiōes do país. Para os fins deste artigo, serão utilizados resultados empíricos colhidos acerca de dez associações criadas entre 1861 e 1880 na cidade do Rio de Janeiro.

A base da presente reflexão encontra-se numa documentação depositada no Arquivo Nacional, que consta de estatutos e atas de associações, enviados para observação e análise da seção de negócios do Conselho de Estado entre os anos de 1860 e 1889 na cidade do Rio de Janeiro. Segundo previa a legislação em vigor, toda associação a ser criada neste período deveria ter seus estatutos e atas de fundação enviados à referida seção para análise e posterior aprovação para que pudesse funcionar. De posse da proposta, os documentos eram analisados e sobre eles eram feitas observações que visavam torná-las adaptadas aos parâmetros considerados ideais e legais, obedecendo a um código de valores compartilhados pelos gestores, no final do Império. Tal código expressava-se não só pelas observações dos conselheiros, mas também através de decretos que regulamentavam o seu funcionamento. ${ }^{4}$ As propostas poderiam ser aprovadas ou reprovadas no todo ou em parte.

Para os fins deste artigo, procedeu-se a uma análise sobre os estatutos e atas das seguintes sociedades: 


\begin{tabular}{|c|c|l|}
\hline 1 & 1861 & Sociedade de Caridade das Senhoras da Corte \\
\hline 2 & 1861 & Associação de São Vicente de Paulo \\
\hline 3 & 1867 & Sociedade Asilo de Inválidos da Pátria \\
\hline 4 & 1874 & Sociedade Filantrópica dos Artistas \\
\hline 5 & 1874 & Sociedade de Beneficência Amparo das Famílias \\
\hline 6 & 1874 & Associação Cosmopolita União e Caridade \\
\hline 7 & 1875 & Associação Asilo e Beneficência \\
\hline 8 & 1877 & Associação de Socorros Mútuos Filantropia e Ordem \\
\hline 9 & 1880 & Imperial Associação Filantrópica Fluminense \\
\hline 10 & 1880 & Sociedade Beneficente Justiceira da Orfandade e Viuvez \\
\hline
\end{tabular}

Com base nesta documentação, objetiva-se responder a questóes que ainda se encontram em aberto sobre o tema. Segundo levantamentos feitos por Silva Jr., 5,25\% da população masculina adulta brasileira era associada a algum tipo de sociedade. Para a cidade do Rio de Janeiro este número chegava a 18\%. Embora seja bem inferior aos indicadores ingleses (um em cada três ou quatro adultos) e próximo ao dos argentinos (6,5\%), o percentual constituía-se no dobro de sindicalizados para o mesmo período. Só por esta razão já se justificaria o estudo do fenômeno associativo no país. ${ }^{5}$

Ademais, as pesquisas sobre o mutualismo e a filantropia, sob o ponto de vista histórico, encontram-se em estágio bastante inicial, o que não ocorre para outros lugares do mundo. No caso específico da filantropia, tendo sido objeto quase exclusivo de análise de sociólogos e/ou assistentes sociais, seus resultados estiveram voltados para as políticas de assistência pública, indicando seu alcance, apontando seus limites e identificando suas transformações ao longo do tempo. Estudos sob uma perspectiva histórica são raramente encontrados e, em geral, versam sobre instituições de proteção social ao idoso e à criança desvalida. ${ }^{6}$

No caso do mutualismo, as abordagens históricas ocorrem em maior número e assumem um caráter bastante regionalizado, dada a vastidão e dispersão das fontes primárias. Trabalhos sobre o Rio de Janeiro, São Paulo, Minas Gerais e Rio Grande do Sul já foram produzidos, sem que análises comparativas pudessem ainda ser feitas e sem que se avançasse mui- 
to na definição precisa do fenômeno, bem como na sua transformação ao longo do tempo. ${ }^{7}$

Com base nas carências apontadas, este trabalho pretende prestar uma contribuição para reflexões sobre uma prática que tinha uma importância muito grande para seus contemporâneos.

\section{1 - Acerca das definições}

Filantropia e mutualismo compunham categorias fluídas, indiferenciadas para os próprios contemporâneos. Várias sociedades que foram criadas no período se autodenominavam "de socorros mútuos", "filantrópicas" ou de "beneficência". O próprio estado imperial teve dificuldades em caracterizá-las, como se pode perceber por este parecer emitido para a Sociedade de Beneficência Amparo das Famílias em 1874: ${ }^{8}$

Esta sociedade não é de beneficência, porém de Socorros Mútuos porque não se destina a prestar socorros aos necessitados que entenda precisarem de seu auxílio e o merecerem.

$\mathrm{Na}$ visão do parecerista, a palavra beneficência seria o equivalente ao que para nós hoje consiste em filantropia, palavra resultante da junção entre os termos gregos philos e antropos que significa a prática de doações em benefício do outro. Com o avanço do cristianismo, o conceito foi associado ao de caridade, relegando o uso da expressão filantropia à necessidade de demarcação das açôes de caráter laico. ${ }^{9}$ As sociedades que não se destinassem a auxiliar os destituídos, mas fossem estruturadas com base na contribuição mensal de recursos pelos sócios com o fim de propiciar-lhes alguma pensão ou benefício em caso de dificuldades, chamar-se-iam de "socorros mútuos" e não de beneficência. Mas ao que parece, os próprios criadores da sociedade proposta tinham dúvidas quanto a sua identidade.

No entanto, em outro parecer relativo à Sociedade Filantrópica dos Artistas, ${ }^{10}$ que, ao que tudo indica, era uma associação de socorros mútuos, embora se autodesignasse como filantrópica, encontramos em seu estatuto a seguinte missão:

Artigo 40: A Sociedade tem por fim beneficiar a seus sócios que forem necessitados, e bem assim, suas famílias, uma vez que provém necessitar dela.(...) 
Artigo 41: As jóias estabelecidas pelo artigo $9{ }^{\circ}$ não deixa de ser livre a qualquer sócio revelar com donativos maiores, sua generosidade e amor a Sociedade; considerando-se o excedente a jóia estabelecida como donativo.

Vê-se que esta sociedade, que possuía 450 sócios e se reunia em uma cervejaria, percebia-se a si mesma como praticante da filantropia, não abrindo mão de recolher donativos derivados da generosidade de seus sócios a serem repassados para a própria sociedade. Mas, na prática, era uma sociedade de mútuo socorro.

Mais fácil, porém, se torna a diferenciação entre as sociedades de socorro mútuo e os montepios. Os montepios funcionavam como seguradoras. Eram sociedades privadas, que visavam lucro e obedeciam às regulamentaçōes do mercado. Proliferaram largamente após 1919, ano de criação da lei de Proteção contra Acidentes de Trabalho, na medida em que eram contratados pelas empresas para prover a cobertura demandada pela lei. Os montepios eram organizações de mercado e obedeciam a valores estritamente econômicos. Já as associações de socorro mútuo, ou beneficentes, compartilhavam de valores extra-econômicos, pois não limitavam sua ação às regras de mercado. Por serem organizações da sociedade civil, primavam pela preocupação em oferecer socorro aos necessitados, que podiam ou não ser seus sócios. As contribuições e as pensões a serem recebidas em caso de necessidade eram previstas pelos estatutos. Mas estes previam também ocasióes em que os não-sócios poderiam ser contemplados com algum tipo de auxílio e apelavam igualmente para a generosidade de seus associados com vistas ao fortalecimento da associação. Essas quantias doadas eram fluidamente determinadas, previstas, mas não quantificadas, revelando a presença de valores extra-econômicos a compor o horizonte dessas sociedades.

Um outro exemplo da fluidez dessas categorias pode ser encontrado na Associação Asilo e Beneficência. ${ }^{11}$ Conforme previa seu estatuto, era uma sociedade de mútuo socorro que, além de socorrer os seus sócios nos momentos de necessidade, tinha como propósito construir um orfanato para cem meninas e cinqüenta meninos. No parecer emitido pelo Conselho de Estado não se corrige o nome da associação e nem se faz referência ao seu duplo papel - mutual e filantrópica -, o que demonstra a fluidez dessas categorias também para os conselheiros que normalmente se colocavam na condição de guardiōes da Lei. 
A visão de tais associaçōes como organizações formais, privadas, sem distribuição de lucros, autogovernadas e voluntárias ${ }^{12}$ pode ser também relativizada. A análise empírica tem apontado a existência de inúmeras sociedades que remuneravam seus associados para o desempenho de algumas funções, o que não as tornava exclusivamente voluntárias. É o caso da Associação acima citada, a qual previa a existência de um gerente tão bem remunerado (de três a seis contos por ano) que levou o Conselho de Estado a questionar o privilégio do cargo e a sugerir que seu ocupante, em vez de ser indicado pela diretoria o fosse pela Assembléia Geral, referindo-se para isto ao "Decreto de 19 de dezembro de 1860, que não admitem mandatários, senão revogarem e substituírem por livre escolha da assembléia geral dos sócios".

Ao mesmo tempo, era impossível a uma mutual sobreviver sem a obtenção de lucro, uma vez que este mesmo lucro era distribuído pelos sócios para o cumprimento de sua missão. Por fim, pouco tinham de autogovernadas, na medida em que a sua diretoria era responsável pela maior parte das decisóes, muitas delas tomadas à revelia de suas assembléias gerais, além do quê, ocorria forte intervenção do Estado sobre o seu funcionamento, pelo menos no momento de sua instalação, como se verá a seguir.

\section{2 - Acerca das relações com o Estado Imperial}

As dubiedades apontadas não se limitavam às definições. Atingiam também as relações entre as associações e o Estado. Ao mesmo tempo em que eram organizações de direito privado, exerciam funções públicas. Este caráter dúbio de organização gerava uma relação de contradição com o Estado. O poder público se sentia obrigado a lhes oferecer o apoio, por estarem desempenhando funções reconhecidamente estatais, mas, as prerrogativas liberais, inspiradoras de nossas classes dirigentes na ocasião, limitavam os investimentos, opção agravada pela carência generalizada de recursos. Assim, muito embora tais agremiações desempenhassem reconhecido papel social, viviam recorrendo à comunidade para solicitar recursos adicionais para a sua manutenção.

A ação do Estado não se limitava à subvenção. Preocupou-se com a sua regulamentação. Os decretos acima referidos compunham um arcabouço legal dentro do qual as associaçóes tinham reduzido campo de manobra. 
Além da obediência aos decretos regulatórios, para que passassem a funcionar, deveriam ter seus estatutos avaliados pelo Conselho de Estado o qual atuava como um guardião do cumprimento da lei e do funcionamento da sociedade. Como se verá, o Estado, através de seu Conselho mais importante, utilizava-se de diferentes critérios no cumprimento de seu desiderato.

De imediato, percebe-se uma preocupação muito grande por parte dos conselheiros com a viabilidade financeira e a perenidade da organização. Sugerem a redução das coberturas, a sua duração, a sua extensão, a periodicidade das reuniōes, a ampliação do número de sócios entre outras coisas.

$\mathrm{Na}$ análise da proposta de criação da Sociedade de Beneficência Amparo das Famílias, ${ }^{13}$ o conselheiro relator chega à conclusão que as coberturas prometidas aos associados eram impossíveis de serem pagas com as arrecadações previstas. Ironizando seus gestores, sugere que o próprio Império se associe à mesma para ter os seus compromissos com pensôes pagos pela referida associação:

O próprio Governo deveria aproveitar a descoberta para que, livrando dos sacrifícios que faz o Tesouro nas pensões e nos meios soldos do Exército e da Marinha dotasse melhor todos os servidores do Estado.

A proposta foi indeferida, com o argumento de que cabia ao Conselho de Estado resguardar os direitos dos associados para que esses não fossem lesados. Justifica desta forma o seu parecer:

Se fosse livre a organização das sociedades, seria de sua própria inexperiência que teriam de queixar-se os iludidos por tão pomposas promessas; porém, tendo o Governo de aprimorar os Estatutos, incorreria em responsabilidade moral, concorrendo para que a autoridade de seu nome servisse para favorecer tais planos.

Na citação percebe-se o papel que o Conselho de Estado se auto-atribuía, que era o de proteger o povo contra as ilusões dos enganadores e contribuir com o aprimoramento dos estatutos. Na condição de juristas e guardiôes da lei, os membros do Conselho de Estado tinham como missão contribuir com a proteção social e com a ilustração do povo.

Esta preocupação é levada ao extremo, quando os conselheiros se recusam a abonar associações que propõem estatutos com erros de ortografia. Em parecer emitido acerca da Associação de Socorros Mútuos Philantro- 
pia e Ordem, ${ }^{14}$ afirma-se que a documentação enviada sugere a existência de "muita ignorância" dado que a proposta "ficaria suposta a interpretações diversas, conforme as boas ou más disposições de ânimo dos intérpretes, que, nestas sociedades, não primam por grandes sabedores”.

O esforço regulatório se manifesta igualmente através da intervenção sobre os cargos criados e o seu funcionamento. Há uma preocupação dos governantes em garantir o poder deliberativo das assembléias gerais, que deveriam funcionar como freios aos arbítrios da diretoria. Há também uma preocupação em evitar-se privilégios, garantindo-se a isonomia de direitos entre os sócios. Ao emitir parecer acerca do estatuto da Associação Cosmopolita União e Caridade, ${ }^{15}$ o Conselho de Estado indefere o pedido de funcionamento da mesma por ter decidido transformar em remidos seus sócios fundadores que haviam se expressado bem e se empenhado pela criação da sociedade, conforme consta da ata de instalação da referida Associação:

Finda a votação dos Estatutos o senhor Joaquim Ladisláo Leal pede a palavra e apresenta a seguinte proposta: que seja conferido os títulos de sócios remidos aos senhores João Antônio dos Santos Delgado, Augusto José Rodrigues da Silva e Thomé Alves da Silva, em prêmio de suas elucubraçôes e virtudes, como iniciadores e organizadores da Associação Cosmopolita Uniāo e Caridade; cuja solução para mais honra dos agraciados será anexo por adição aos Estatutos, sendo posta a votos foi aprovada a proposta.(grifos nossos).

Para os membros do Conselho esta decisão feria os interesses dos demais associados, embora seus 203 sócios ( 151 homens e 52 mulheres) a tivessem aprovado por unanimidade e com regozijo. Como guardião da ilustração, da eqüidade entre os pares e agora da "Ciência", manifestou-se a este respeito o Conselheiro: "Devem, pois, os requerentes sujeitar-se às regras que a ciência ensina que devem ser guardadas nestas organizações, e formulados outros Estatutos dará então a Seção seu parecer sobre eles." Não bastava que as assembléias se reunissem e deliberassem. O Conselho se colocava no direito de indeferir as escolhas dos associados, respaldado na nobre missão de garantidor da ciência, das leis e das letras.

Encontramos entre as dez associaçóes analisadas, uma que se contrapôs com veemência aos arbítrios do Conselho. Em geral, demorava-se muito até que o parecer fosse emitido. Após o pedido ser registrado na se- 
cretaria de negócios, a associação esperava, em geral, mais de um ano para obter o aval pretendido. Pelo que foi possível perceber, a ausência do parecer não impedia o funcionamento da mesma, mas a deixava numa situação de fragilidade e inviabilizava a obtenção de subvenções públicas.

Este foi o caso da Associação Filantrópica Fluminense, ${ }^{16}$ uma mutual de tipógrafos fundada em 1853 e que solicitou uma reforma em seu estatuto em 1880. Passados dois anos do pedido, a Associação não tinha permissão para fazer a reforma desejada em função de uma discordância pontual de um conselheiro, que insistia que constasse no estatuto que a sociedade deveria atender os pobres. Os sócios não acataram a sugestão do Conselheiro, embora reconhecessem que os tipógrafos fossem pobres, mas se sentiam lesados por esta exigência não ter sido feita a outras sociedades congêneres. Para o Conselheiro, a ausência da palavra pobre transformava a mutual em montepio, com o que seus sócios não concordavam. Como se viu anteriormente pairavam muitas dúvidas acerca das definições das sociedades. Como esta associação não visava lucro e era baseada na ajuda mútua, não se via como um montepio e se intitulava filantrópica, embora fosse uma mutual de ofício. Diante da resistência do conselheiro, os membros recorreram à intervenção do Imperador, alegando que:

Perante V. M. Imperial recorre ainda uma vez o Conselho da Imperial Associação Tipográfica Fluminense a solicitar a sanção da reforma de seu Estatuto que há dois anos se acham na Secretaria do Império, devido a algumas emendas exigidas pela Ilustre Seção dos Negócios de Império de Conselho de Estado. Senhor, as atestadas emendas como V. Majestade poderá verificar (...) mandam acrescentar a palavra - pobre - ou - atestado de pobreza; emendas essas de que se pode prescindir, porquanto diversas sociedades de iguais (ilegível) como sejam: empregados da Tipografia Nacional, empregado da Gazeta de Notícias, Perfeita Amizade, carpinteiros e marceneiros, União e Beneficência e outras, têm tido no decorrer desse tempo o prazer de ver aprovados os seus estatutos sem esta cláusula (...) Acresce que esta Associação fundada em 1853, tem caminhado até em progressivo desenvolvimento, e tendo o Governo Imperial por duas vezes aprovado os seus Estatutos sem a exigência das referidas emendas, em artigos que em nada ferem as disposições das leis do Estatuto, não parece justo que seja obrigada hoje a aceitá-las, alterando o pensamento de seus fundadores em artigos que não lhe dão o caráter de Montepio, porquanto a Associação só socorre aos associa- 
dos quando enfermos. Senhor. - O Conselho da Imperial Associação confiado na Justiça que precede os atos de V. Majestade Imperial pede que, ouvindo a respectiva seção dos Negócios do Império do Conselho de Estado, haja por bem sancionar os ditos estatutos (...) (grifos nossos).

Temendo que o Imperador fizesse valer a vontade dos associados, o conselheiro o lembrou que:

Mais de uma sociedade de beneficência e socorros mútuos tem recusado conformar-se com as emendas feitas pela seção neste sentido, e a seção os tem constantemente sustentado; não, pois, hoje retratar-se." (...) O que nem a Secretaria, nem o Conselho de Estado, nem o Governo Imperial podem fazer, porque acima de todos está a Lei, é imprimir uma expressão, que caracteriza a natureza da sociedade de beneficência e a distingue de - Montepio -, que é constituído e regulado por modo diverso (grifos nossos).

Como se nota pelas palavras dirigidas ao Imperador, os pleiteantes clamavam por justiça, por sentirem que as regras que garantiam a eqüidade no tratamento haviam sido quebradas. Não sabemos que fim foi dado ao pleito, pois a documentação não está completa. Embora tenha sido, até agora, um fato único, serve para nos alertar que as reaçóes contra as contínuas intervenções do Conselho de Estado sobre o cotidiano das sociedades existiam.

\section{3 - Acerca das motivações}

Boa parte dos trabalhos existentes sobre a filantropia e o mutualismo está centrada nas razôes que levariam os indivíduos à prática da caridade e da cooperação mútua. A este respeito delineiam-se quatro correntes.

A primeira delas explica a prática da ajuda mútua como resultado de incentivos por parte do Estado com vistas à garantia do controle social. Tal corrente se expressou através do conceito de poder pastoral. ${ }^{17}$ Para Foucault, o poder pastoral é uma forma de poder voltada para o indivíduo com o fim de garantir-lhe a salvação eterna. Ele é sempre vertical, sacrificial, salvacionista e individualizante. $\mathrm{O}$ peso deste poder sobre o homem o conduziria à busca infinda pela salvação eterna, o que explicaria 
seu comportamento altruísta e, na longa duração, o advento da filantropia e do Estado de Bem-Estar Social.

A segunda corrente explica o comportamento doador e cooperativo do homem a partir dos parâmetros da psicologia social. Segundo esta visão, a personalidade altruística resulta de um aprendizado na infância que prioriza o estabelecimento de relaçóes pessoais por sobre a obtenção de status como formas de gratificação obtidas na vida. A partir deste aprendizado, a pessoa é levada a estabelecer relações solidárias, mesmo com aquelas que não fazem parte de sua intimidade. ${ }^{18}$

A terceira corrente inspira-se na teoria dos jogos que, originada nos paradigmas utilitaristas, tem asseverado que as relações solidárias e altruísticas são sempre relações individuais de troca, na medida em que o doador é racionalmente motivado a expandir ao máximo os seus ganhos pessoais, obtendo como resultado imediato de sua doação a aprovação social e a gratidão do receptor. ${ }^{19}$

Por fim, a quarta corrente que se reúne em torno das teorias da reciprocidade, a qual daremos maior destaque, por considerarmos a mais adequada para a explicação das razóes que conduzem os seres humanos a assumirem comportamentos mais solidários.

Segundo o antropólogo Maurice Godelier, pertencer a um grupo nas sociedades primitivas já era garantia de sobrevivência. Já na sociedade capitalista, a exclusão social é a marca do não pertencimento. Com o fim de resolver este dilema, a própria sociedade capitalista incentivou a prática da ajuda mútua e da cooperação, que, quando institucionalizadas, cumpririam um papel importante na manutenção desta mesma sociedade. ${ }^{20}$

Karl Polanyi nos informa que em sociedades caracterizadas pela ausência de um mercado formal, as relações de troca expressam princípios alternativos ao comportamento econômico capitalista de tipo competitivo, pois a reciprocidade passa a reger as permutas. A reciprocidade - que pode ser entendida como atos isolados de dar, receber e contradoar - requer aceitação de regras (não necessariamente escritas) e a existência de confiança mútua, sentimentos que obliteram a bipolaridade das relações sociais de troca, amenizando a luta competitiva. ${ }^{21}$

Como o período de emergência e proliferação das associações se deu previamente ao período de plena expansão das relações capitalistas de tro- 
ca, a reciprocidade fundamentava as relações de doar, receber e contradoar. Marshall Sahlins identifica dois modelos de reciprocidade: a balanceada e a generalizada. ${ }^{22} \mathrm{~A}$ balanceada opera no ambiente onde as trocas são iguais. A generalizada prepondera nas relações onde alguém contribui com mais do que recebe, sabendo que em algum momento, receberá de volta o valor contribuído anteriormente.

Novamente Maurice Godelier ${ }^{23}$ nos alerta para a importância das noções que envolvem as dádivas, o seu recebimento e a sua devolução (contradom). Para o antropólogo, a prática das doaçóes envolve sempre a expectativa de devolução da oferta por parte do contemplado, mesmo que o retorno da dádiva concedida seja a manutenção do receptor na condição de dependente do doador. Complementa esta noção a abordagem de Pierre Bourdieu ${ }^{24}$ sobre a prática de atos aparentemente desinteressados. O autor, em seus estudos das trocas simbólicas, nos informa que doações aparentemente desinteressadas escondem o interesse pelo acúmulo, por parte do doador, de capital político ou simbólico, materializados pelo reconhecimento do poder de quem ofertou.

O conceito de reciprocidade nos auxilia, assim, a escapar de uma visão maniqueísta da sociedade, dividida entre indivíduos altruístas e egoístas. Todas as relações de solidariedade prevêem algum tipo de reciprocidade mesmo que o retorno do bem (contradom) seja tardio ou indireto. A reciprocidade não precisa igualmente ser bipolar e nem requer a paridade entre doadores e receptores. Muito embora o pobre não possa retribuir materialmente o bem recebido, os ganhos do doador são indiretos e podem ser expressos através de um reconhecimento social (poder simbólico, na visão de Bourdieu), uma vantagem política adicional, ou mesmo uma satisfação pessoal por sentir-se responsável pela desigualdade social (alívio da culpa).

As regras de funcionamento da Sociedade São Vicente de Paulo ${ }^{25}$ expressam bem o ritual do dom e do contradom citados acima. Considerava-se como objetivo precípuo da Associação "levar consolações ao enfermos e aos encarcerados, de instruir as crianças pobres, desamparadas ou reclusas, e de prestar socorros religiosos aos que deles carecerem em artigo de morte". Para a realização desses nobres intentos, eram realizadas reuniôes em que os sócios publicamente revelavam a quem eles pretendiam ajudar. Refere-se a este prática o artigo 20 de seu estatuto: 
Cada membro é chamado por sua vez pelo Presidente, e diz em voz alta o que pede e para quantas famílias. Quando a isso o convidam, dá informações sobre essas famílias. Os socorros devem ser levados exatamente aos pobres no intervalo, que decorre de uma sessão a outra. A ocasião, o número e o modo das visitas ficam cometidos à prudência de cada membro, como também os meios que hajam de empregar-se para introduzir no seio das famílias o amor da religião e a prática dos seus deveres. Ouvir-se-ão atenciosamente com benevolência aquelas pessoas que pedirem regras para o seu comportamento, ou conselhos em lances difíceis, e o Presidente, ou qualquer outro membro, dar-lhes-ha as respostas que lhe forem sugeridas pela sua experiência e caridade.

Nota-se que a doação estava condicionada ao merecimento do receptor, avaliado pelo conjunto de sócios. As contribuições eram públicas, constituindo-se em oportunidade de afirmação de status e poder e o dom oferecido envolvia a emissão de conselhos e de regras de comportamento, expressão de que era aceito pelo receptor. Completava-se, assim, o ciclo de doar, receber e contradoar.

$\mathrm{O}$ exemplo acima nos remete às análises antropológicas de Marcel Mauss $^{26}$ que afirma que quando se doa aos pobres, presume-se que eles não possam contradoar a oferenda, por não terem recursos. Para Mauss, no entanto, nesses casos a reciprocidade estaria garantida para o doador, que receberia o contradom sob a forma de reconhecimento social de sua benevolência, de poder político que poderia resultar de sua ação ou simplesmente do prazer em subsumir um ser ao seu arbítrio, tal como vimos acontecer no exemplo acima.

\section{4 - Acerca das diferentes moralidades}

Com base nas reflexões acima expostas, pode-se aventar que as experiências de ajuda mútua sejam resultantes de escolhas individuais. No entanto, o foco sobre as instituições e não sobre os indivíduos tem revelado o contrário. Predominava um código de valores tacitamente compartilhados que regulava as ações do Estado e das associaçóes. Nos casos analisados, tratavam-se de associaçóes que, à revelia de sua denominação - por elas próprias conferidas ou impostas pelos membros do Conselho de Estado - tinham como principal valor a ser preservado o da ajuda mútua. 
Nos levantamentos feitos por Donillen Loseke dos discursos em prol da filantropia, publicados na imprensa nova-iorquina entre os anos de 1912 e 1992, inferiu-se que havia diferentes tipos de moralidades que condicionavam tais práticas, como o da moralidade sagrada religiosa, a moralidade sagrada da democracia comunitária, a moralidade econômica do capitalismo individualista e a moralidade humana da compaixão, o que a levou a afirmar que:

Ao invés de perguntar se os indivíduos praticam caridade porque são altruístas ou a fazem por ser um método de controle social ou porque tais atos podem resultar no fortalecimento da reputação do doador, devemos reconhecer que esta idéia contém múltiplos vocabulários de moralidades. ${ }^{27}$

Essas diferentes moralidades, que extrapolam as opções meramente individuais, encontravam-se presentes nas associações de ajuda mútua e manifestavam-se através de alguns valores. O espírito da competição e o da avidez pelo lucro era recriminado, bem como o da heteronomia. Todos os associados deveriam ter os mesmos direitos e se empenhar pelo bem comum. Todas as sociedades que fugiam a este princípio eram convidadas a mudar a sua identidade para a de montepio ou mesmo não eram autorizadas a funcionar. Comportamentos dissonantes eram malvistos pelos sócios.

Predominava também o valor de hierarquia com base no mérito adquirido pelo saber ou pelo compromisso com o bom êxito das associações. Grandes contribuintes teriam mais poder sobre as sociedades. Os mais sábios também, conforme se depreende do episódio ocorrido na Associação Cosmopolita União e Caridade, ${ }^{28}$ quando da escolha de seu presidente interino:

pedindo a palavra o senhor Cruz Teixeira a faz ver a todos os senhores que se acharam reunidos demonstrando o quanto era inteligente, a pessoa do senhor Santos Delgado que sabiamente conhecia o reger os destinos de uma associação, e convicto nisso propunha que fosse o mesmo senhor proclamado Presidente, que sendo posto a votos, foi unanimemente aprovado (grifos nossos).

Muito embora imperassem nas associações os valores da solidariedade mútua, não se confiava muito nos sócios. A maior parte dos estatutos previa a criação de uma comissão conhecida como "hospitaleira", que era responsável por visitar os doentes e conferir se seu estado de saúde realmente demandava algum tipo de auxílio. 
Ainda em relação às diferentes moralidades compostas por este conjunto de valores, um fato ocorrido na Sociedade Beneficente Justiceira da Orfandade e Viuvez ${ }^{29}$ nos revela uma aparente incongruência, que, no entanto, se encaixava perfeitamente no arcabouço moral em vigor, já demonstrado por outras fontes. A sociedade havia sido criada como filantrópica e beneficente, mas tinha como fonte de renda a compra de direitos de ações judiciais de terceiros. Assim se expressou o conselheiro acerca deste original artifício: "A compra de direitos e ações de terceiros, para o fim de lucrar com as demandas e execuções judiciárias, é uma especulação tolerada, mas não autorizada, no rigor do termo, pela nossa legislação."

Ou seja, as especulações com direitos alheios embora não fossem legais, poderiam até ser toleradas pelo Conselho. $\mathrm{O}$ que não se admitia era a dubiedade acerca do caráter da associação, que teve a sua proposição indeferida, não por ser ilegítima, mas por ter sua identidade confusa e seus estatutos mal redigidos. Assim encerrava o parecer: "O fim da sociedade não direi que seja ilícito,[mas] tenho dúvida acerca da sua pública utilidade, e em todo caso julgo imerecida a qualificação que se lhe dá de beneficente." Percebe-se neste exemplo uma preocupação maior do parecerista com a identidade da associação, para que a lei fosse cumprida, do que com os eventuais prejuízos que pudesse causar aos associados. O cumprimento da lei estava acima do interesse dos associados.

As moralidades comportavam também tratamentos diferenciados, a despeito da propalada isonomia. A dureza dos conselheiros não era dirigida a todos indistintamente, mas previa exceções, como a observada em relação ao pedido de aprovação do estatuto da Sociedade de Caridade das Senhoras da Corte. ${ }^{30} \mathrm{Tal}$ renomada sociedade destinava-se a prestar socorros às vítimas de uma epidemia e assumia um tom declaradamente filantrópico. Seus membros, só mulheres, pediriam esmolas na rua, sempre acompanhadas e nunca a sós, com o fim de arrecadar doaçôes em socorro dos enfermos. Porém, seu maior mérito encontrava-se no fato de ser dirigida pela Marquesa de Olinda e secretariada por uma baronesa e uma viscondessa. Este singelo fato amenizou em muito as relações com o Conselho, o qual emitiu parecer favorável, a despeito das inúmeras lacunas existentes no estatuto, que por muitas vezes e por muito menos, impediram o funcionamento de outras associações. Assim se pronunciou o conselheiro: 
Em cumprimento da determinação Imperial a Seção examinou esses abreviados estatutos, e viu que eles não são senão a expressão simples e resumida de um belo pensamento, ou da louvável idéia da caridade que anima esta digna e sutil associação.

Pode-se alegar que o perfil exclusivamente filantrópico da referida sociedade viabilizasse a aprovação de seu estatuto, mesmo que incompleto. Mas o mesmo não ocorreu quando a Sociedade São Vicente de Paulo, ${ }^{31}$ também exclusivamente filantrópica, submeteu seu estatuto ao Conselho de Estado. Por tratar-se de cópia traduzida de estatuto francês, o Conselho condicionou a sua aprovação à realização de inúmeras mudanças, revelando um tratamento diferenciado para associações de um mesmo perfil. Como se vê, o afã do Estado em regulamentar e fazer-se presente na construção de uma imagem de guardião da justiça, da ciência e das letras esvaía-se na prática de favorecimentos individuais de caráter personalístico e na discriminação infundada de alguns setores sociais, revelando os limites e as contradiçõos de um Estado portador de um discurso liberal e isonômico.

Desta forma, as práticas que retratam tais valores devem ser lidas como artefatos culturais para os quais se deve estar atento, sobretudo em suas formas de expressão que são a linguagem, os rituais e os símbolos. É preciso, então, perceber como a idéia da ajuda mútua foi construída e expressa e como se reproduziu a retórica da doação. Em síntese, na presente pesquisa não se analisa o comportamento do doador como expressão de mero interesse individual pela ajuda mútua sem levar-se em conta a presença de uma ética social internalizada que impulsione as ações cooperativas.

\section{Concluindo}

Como vimos, uma nova história dessas formas de associação poderia contribuir para uma história social dos valores normativos forjados na sociedade brasileira. Percebe-se que em algumas culturas a responsabilidade social é mais valorizada que em outras. A prática da ajuda mútua é distinta em cada sociedade. Estudos comparativos precisam ser feitos para o melhor entendimento dessas realidades.

Ao usar alguns paradigmas da História Cultural, optou-se por abrir mão da análise dos motivos exclusivamente individuais responsáveis por gerar 
comportamentos mutualistas e filantrópicos que, em geral, não levam em conta os processos culturais gerais em andamento. Acredita-se que havia uma cultura solidária que reforçava valores de cooperação e de ajuda mútua.

Destacou-se também o caráter dúbio das associações, pois nelas se mesclavam valores tradicionais como os da economia moral do dom e também valores contemporâneos como os do lucro. Compartilhavam suas arrecadações de uma maneira solidária e cooperativa, mas também excluíam sócios inadimplentes (mutuais) ou recusavam-se a ajudar aos pobres que não se comportavam segundo suas expectativas (filantrópicas), além de desconfiarem de seus membros.

Muito embora possam aparecer como espaços de constituição de uma identidade de classe, reproduziam lideranças estabelecidas no poder, na medida em que enalteciam líderes políticos através de várias práticas simbólicas, a exemplo da nomeação de pavilhōes em homenagem aos mais ilustres contribuintes, o agradecimento público na imprensa local de alguma oferta mais generosa de algum político destacado ou o envolvimento em disputas eleitorais em favor de um ou outro candidato, cuja relação com a associação seja mais próxima.

Atualmente, acompanhamos a proliferação de ações filantrópicas leigas que vêm sendo inclusive incentivadas por correntes políticas menos afeitas ao Estado de Bem-Estar Social. As ONGs vêm cumprindo um papel cada vez mais efetivo na institucionalização da ajuda mútua. Paralelamente, a mídia tem incentivado as contribuições sociais, estabelecendo competições públicas entre os maiores doadores. As dádivas tornaram-se institucionalizadas e o dom passou a ser um ato que liga sujeitos abstratos. $^{32} \mathrm{~A}$ ajuda mútua deixa de ser bipolar e passa a ser mediatizada por organizaçoos nacionais e internacionais destacadas e com forte inserção política e social. Recentemente, em vários países europeus se propõe o abandono definitivo das idéias do Welfare State em prol da chamada "cidadania ativa”, através da qual as políticas de amparo social ficariam a cargo da sociedade civil e não do Estado, mesmo que parcialmente por ele subsidiadas. ${ }^{33}$ Identificar como esta cultura de doação se transformou ao longo do tempo de pessoal (economia moral do dom) à impessoal (economia moral do lucro), ${ }^{34}$ de uma moral da ajuda espontânea para uma moral da ajuda incentivada constitui um interessante programa de estudos, para o qual esta modesta pesquisa espera estar contribuindo. 


\section{Notas}

${ }^{1}$ THOMPSON, E.P. A formação da classe operária inglesa. 3aㅡ ed., Rio de Janeiro: Paz e Terra, 2001.

${ }^{2}$ HOBSBAWM, Eric. Mundos do trabalho: novos estudos sobre história operária. 3르. ed., Rio de Janeiro: Paz e Terra, 2000, p. 260, 281 a 283.

${ }^{3}$ Em alusão ao artigo "On Resisting Resistance” de Michael F. Brown. American Anthropologist, 98 (4), 1996.

${ }^{4}$ De acordo com as disposições da Lei no 1.083 (agosto/1860), do Decreto n 2.711 (dezembro/1860) e do Decreto ${ }^{\circ} 2.759$ (março/1861).

5 SILVA JR., Adhemar L.da. As sociedades de socorros mútuos: estratégias privadas e públicas. Estudo centrado no Rio Grande do Sul - Brasil, 1854-1940. Tese de Doutorado apresentada ao Programa de Pós-Graduação da PUC, Porto Alegre, 2005. No ano de 1917 havia 960 mutuais só no Estado do Rio de Janeiro. Para os dados da Argentina ver: MUNCK, Ronaldo. Mutual Benefit Societies in Argentina: workers, nationality, social security and trade-unionism. Journal of Latin-American Studies, vol. 30, 1998. Para os dados da Inglaterra ver: KIDD, Alan. Civil Society or the State? Recent Approaches to the History of Voluntary Welfare. Journal of Historical Sociology, vol.15, n. 3, September, 2002, p. 333. Na Inglaterra, o percentual de sindicalizados variava de $10 \%$ a $15 \%$. No Brasil, era a metade dos mutualizados.

${ }^{6}$ Destacamos, entre outros trabalhos, os seguintes: DEL PRIORI, Mary. (org.) História da criança no Brasil. São Paulo: Contexto, 1992; FREITAS, Marcos C. (org.) História social da infância no Brasil. São Paulo: Cortez, 1997. SOUZA, Marco A. de. A economia da caridade: estratégias assistenciais e filantrópicas em Belo Horizonte. Belo Horizonte: Ed. Newton Paiva, 2004. NEGRĀO, Ana Maria M. Infância, educação e direitos sociais: Asilo de órfäs (1870-1960). Campinas: Unicamp, 2004.

${ }^{7}$ LUCA, Tânia R. de. O sonho do futuro assegurado: o mutualismo em São Paulo. São Paulo: Contexto, 1990. BATALHA, Cláudio H.M. Sociedades de Trabalhadores do Rio de Janeiro do Século XIX: Algumas reflexões em torno da formação da classe operária. In: CADERNOS DA AEL, op. cit. JESUS, Ronaldo P. de. O Povo e a Monarquia: a apropriação da imagem do imperador e do regime monárquico entre a gente comum da corte (1870-1889). Tese de Doutorado apresentada ao programa de Pós-Graduação em História da USP. São Paulo 2001. VISCARDI, Cláudia M.R. As experiências mutualistas em Minas Gerais: um ensaio interpretativo. In: ALMEIDA, Carla M. de.; OLIVEIRA, Mônica R. de. (orgs.) Nomes e números: alternativas metodológicas para a história econômica e social. Juiz de Fora: EdUFJF, 2006, p. 305-322. SILVA Jr., Adhemar, op. cit.

${ }^{8}$ Arquivo Nacional, caixa 552, código 128.

${ }^{9}$ MESTRINER, Maria Luiza. O estado entre a filantropia e a assistência social. São Paulo: Cortez, 2001, p. 19.

${ }^{10}$ Arquivo Nacional, caixa 552, código 100.

${ }^{11}$ Arquivo Nacional, caixa 553, código 138. 
${ }^{12}$ Conforme definição de Johns Hopkins Corporative Non-Profit Sector Project, citadas em: KIDD, Alan. Civil Society or the State? Recent Approaches to the History of Voluntary Welfare. Journal of Historical Sociology, vol. 15, n. 3, sep., 2002, p. 335, apud.

${ }^{13}$ Arquivo Nacional, caixa 552, código 128.

${ }^{14}$ Arquivo Nacional, caixa 555, código 183.

${ }^{15}$ Arquivo Nacional, caixa 552, código 103.

${ }^{16}$ Arquivo Nacional, caixa 557, código 229.

${ }^{17}$ FOUCAULT, M. Omnes et singulatin: uma crítica da razão política. In: Estratégia, poder-saber. Organização e seleção de textos de Manoel Barros da Motta. Rio de Janeiro: Forense Universitária, 2003. Uma nova leitura deste conceito relacionada diretamente à filantropia feminina pode ser vista em: DRENTH, Annemieke V.; HAN, Francisca de. The rise of caring power. Amsterdam: Amsterdam University Press, 1999.

${ }^{18}$ KIDD, Alan. Philanthropy and the social history paradigm. Social history review, vol. 21, n. 2, may, 1996, p. 185, apud.

${ }^{19}$ RAPOPORT, Anatol. Lutas, jogos e debates. Brasília: UNB, 1980.

${ }^{20}$ GODELIER, Maurice. O enigma do dom. Rio de Janeiro: Civilização Brasileira, 2001, p. 9.

${ }^{21}$ POLANYI, Karl. A grande transformação: as origens de nossa época. $2^{\underline{a}}$ ed., Rio de Janeiro: Campus, 2000, p. 68, 81 e 82.

22 SAHLINS, Marshall. Stone age economics. Chicago: Aldine-Atherton, 1972.

${ }^{23}$ GODELIER, Maurice. Op. cit. Introdução e cap. 1.

${ }^{24}$ BOURDIEU, Pierre. Razões práticas: sobre a teoria da ação. Campinas: Papirus, 1996, cap. 5 .

${ }^{25}$ Arquivo Nacional, caixa 575, código 173.

${ }^{26}$ MAUSS, Marcel. Ensaio sobre a dádiva. Edições 70, Lisboa.

${ }^{27}$ LOSEKE, Donillen. The construction of the idea of charity (1912-1992). Social problems, (4), 1997, p. 425-444.

${ }^{28}$ Arquivo Nacional, caixa 552, código 103.

${ }^{29}$ Arquivo Nacional, caixa 557, código 223.

${ }^{30}$ Arquivo Nacional, caixa 526, código 354.

${ }^{31}$ Arquivo Nacional, caixa 575, código 173.

${ }^{32}$ GODELIER, M. Op. cit., p. 25.

${ }^{33}$ KIDD, Alan.The liberal state: civil society and social welfare in XIX Century England. Journal of Historical Sociology, vol. 15, n. 1, march, 2002, p. 114.

${ }^{34}$ Acerca desses conceitos ver: MAUSS, Marcel. Op. cit. 


\section{RESUMO}

A presente pesquisa reúne algumas reflexóes acerca da prática da filantropia e do mutualismo no Brasil, a partir da análise de estatutos e atas de fundação de algumas associaçôes de ajuda mútua do Rio de Janeiro, entre os anos de 1860 e 1889. A partir da análise dessas fontes, pretende-se entender como tais associaçōes se estruturavam; como elas se viam e viam a sociedade na qual se encontravam inseridas; como se processavam as relações entre as associações e o Estado Imperial e entre elas e as outras associaçôes civis existentes; entender as motivaçôes que levavam as pessoas à prática da ajuda mútua; perceber os valores, rituais e crenças que eram compartilhados pelos seus membros; e, por fim, dimensionar o impacto deste processo associativista sobre a cultura civica em vigor.

Palavras-chave: associativismo, filantropia, cultura civica, Império.

\section{ABSTRACT}

This research deals with the friendly and philanthropic societies in Brazil through the research over the statutes and foundation acts of some associations created in Rio de Janeiro between the years of 1860 and 1889. Through the analysis of these sources we intend to understand how societies organized themselves; how their built a selfperception and how were their relationships with the Imperial State. Also, it intends to understand the main motives responsible to influence people into philanthropic behaviors; to perceive shared values, rituals and beliefs; and last but not least, to specify the impact of the associative process over the construction of a civic culture in Brazil.

Keywords: associativism, philantropic behaviors, civic culture.

Recebido em novembro de 2006 e aprovado em maio de 2007 